\title{
On Yedinci Yüzyıl Bilim Devriminin Hazırlayıcısı Olarak Mediciler ve Michelangelo
}

\section{Cem KAMÖZÜT*}

\begin{abstract}
Özet
Galileo'nun öncülük ettiği bilimsel devrimde kilit rol oynayan bazı düşünceler Rönesans ile ortaya çıkmıştır. Medici ailesinin bilinçli çabaları sonucu yaşanan Antik Yunan'ın yeniden keşfi süreci, Michelangelo'nun çabalarıyla başlamış ve Galileo ile sürmüştür. Bu çalıșmada hem Michelangelo'nun hem de Galileo'nun konularına Platonist bir tavırla yaklaştıklarını ve Medicilerin desteğinin tüm bu devrim boyunca yaşamsal olduğunu göstermeye çalıştım.
\end{abstract}

Anahtar Sözcükler: Galileo, Michelangelo, Rönesans, Medici Ailesi

\section{The Medici Family and Michelangelo as The Forerunner of 17th Century Scientific Revolution}

\begin{abstract}
Some of the ideas that played a crucial role during The Scientific Revolution which Galileo led emerged during Renaissance. The process of rediscovery of Ancient Greek started with Michelangelo and proceeds with Galileo, with the conscious efforts of Medici family. In this paper I tried to show that both Michelangelo and Galileo had a Platonist attitude towards their subject matter and that the support of Medici family was vital throughout this revolution.
\end{abstract}

Keywords: Galileo, Michelangelo, Renaissance, The Medici Family

Galileo 8 Ocak 1642 tarihinde Kilise tarafindan verilen ev hapsi cezasındayken öldüğünde Toskana Grandüklüğü kendisi için görkemli bir anıt mezar yaptırmak istemişti. Ancak Kilise'nin cezalandırdığ 1 birine böyle bir anıt yaptırmanın uygun olmayacağı Kilise tarafindan belirtildiğinde, anıttan vazgeçilerek sade bir biçimde gömülmüştü. 1737 yılında, bilimsel çalışmalarının değeri herkes tarafından kabul edilen saygın bir bilimci olarak Michelangelo'nun mezarının karşısında bir mozoleye nakledildi.

\footnotetext{
* Yard. Doç. Dr., Ege Üniversitesi, Edebiyat Fakültesi, Felsefe Bölümü, İzmir Kamözüt, Cem. (2015) “On Yedinci Yüzyıl Bilim Devriminin Hazırlayıcısı Olarak Mediciler ve Michelangelo", Kilikya Felsefe Dergisi, (1) s. 23-43.
} 
Galileo'nun Michelangelo'ya olan hayranlığı nedeniyle özenle seçilmiş bir yerdi burasi. Galileo'nun ilk biyografisini yazan öğrencisi Vincenzio Viviani de biyografide bu hayranlığı vurgulamanın ötesinde Galileo'nun doğum tarihini üç gün kadar değiştirerek 18 Şubat 1564 olarak göstermiş böylece Michelangelo'nun ölüm tarihiyle çakışmasını sağlamıştı. Bugünden bakıldığında bu hayranlık estetik zevklere de sahip bir bilimcinin bir sanatçıyı beğenmesi olarak sıradan bir durum gibi algılanabilir. Floransa'daki Medici ailesinin hem Michelangelo'ya hem de Galileo'ya koruyuculuk yapmış olması da ilginç bir tesadüf olarak düşünülebilir. Ancak bu yazıda Floransa'da Medicilerin bilinçli çabasıyla başlayan İtalyan Rönesans'i ile Galileo'nun öncülük ettiği on yedinci yüzyıl bilim devrimi arasındaki ortaklıkların tesadüf olamayacak kadar fazla olduğunu ve Galileo'nun, Viviani'nin sunduğundan çok daha güçlü bir anlamda Michelangelo'nun başlattığı bir devrimi sürdürdüğünü göstermeye çalışacağım. Kanımca Michelangelo ve Galileo iki ayrı alanda çalışan dehalar değil, aynı düşünsel devrimin parçalarıdır.

Vurgulayacağım paralellikler gerek Rönesans sanatı gerekse bilim için sıklıkla dile getirilen "gözlemsel verilerin kullanımı"ndan ibaret olmayacak. Kuşkusuz Rönesans ile birlikte ikonaların yerini "gerçekçi" dediğimiz resimler almıştır. Sembolik denebilecek anlatımların yerini, hazırlanmasında canlı modeller kullanılan, anatomik ayrıntılara uygun, perspektif kullanımıyla derinlik yanılsaması yaratan eserler almıştır. Bilim devrimi de teleskop gibi gözlem araçlarının gelişimine dayanan bir süreçle ortaya çıkmıştır. Buna karşın göstermeye çalışacağım gibi Rönesans eserleri yalnızca teknik bir anlamda "gerçekçi"dir. Galileo'nun bilimsel çalışmaları da benzer biçimde, duyu verilerine ilk bakışta oldukça aykırı sonuçlar dayatabilen, yalnızca teknik anlamda "gözlemsel" çalışmalardır. $\mathrm{Bu}$ terimlerin gündelik yaşamdaki kullanımları s1k s1k, hem Rönesans sanatını hem de on yedinci yüzyıl bilim devrimini yanlış anlamaya yol açmaktadır. Rönesans eserlerinin asla "fotoğraf gibi" olmadığını ve Galileo'nun da-Ernst Mach'ın savunduğunun aksine - salt deneysel bilginin peşinden koşmadığını göstermeye çalışacağım.

Bu yazıda öncelikle neden Rönesans dönemi eserlerinin yalnızca dar anlamıyla gerçekçi olduğunu söyleyebileceğimizi göstereceğim. Daha sonra Galileo'nun bilimsel yönteminin nasıl olup da duyu verilerine aykırı sonuçlara yol açtığını anlatmaya çalışacağım. Böylece her iki etkinlikte de ortak bir Platonizm bulunduğunu ve benzer bir bilgi kuramına 
dayandıklarını göstermeye çalışacağım. Bunu yaparken neden bütün bu süreçlerin odağında Floransa ve Medici ailesi olduğuna da 1şık tutacağım.

\section{Davut Neden Çıplak?}

Rönesans ile ortaya çıkan yeni sanat anlayışı öncesi Avrupa'da kiliseleri süsleyen eserler ağırlıklı olarak kutsal metinlerdeki öyküleri anlatan eserlerdi. Bunlar Kutsal Kitap'taki on emirden biri olan "imge yapmayacaksın" yasağına uygun olarak, var olan hiçbir șeyle fazla görsel benzerlik taşımıyorlardı. Okuryazar olmayan insanlara din adamlarının anlattıkları öyküleri anımsatacak süslemeler olarak görülüyorlardı. Bu eserleri ortaya koyan sanatçılar, yaratıcılıklarını kullanarak özgün eserler oluşturan kişiler değil, belirli bir siparişi istendiği gibi hazırlaması beklenen kişilerdi. Yalnızca anlatılacak öykü değil onun nasıl anlatılacağı hatta bazen hangi boyaların kullanılacağı bile işveren tarafından belirleniyordu. $\mathrm{Bu}$ nedenle eserlere imza atmak da söz konusu değildi.

Bunlar her ne kadar Rönesans ile değiştiyse de değişim oldukça yavaş gerçekleşti. Michelangelo, da Vinci ya da Raffaello gibi en önemli sanatçılar bile siparişle çalışmaya devam ediyorlard1. ${ }^{1}$ Michelangelo kendini bir heykeltıraş olarak görüyor ve yalnızca mermer heykeller yapmak istiyorduysa da bazı önemli kişilere itiraz edemeyerek çeşitli freskler de yapmıştı. Özellikle Papa II. Julius'un emriyle istemeyerek de olsa dev bir bronz heykel ve Sistine şapelinin ünlü fresklerini yapmıştı.

Michelangelo'nun aldığı siparişlerden biri de bir Davut heykelidir. Floransa Cumhuriyeti ellerindeki mermer bir bloktan-aşağıda açıklayacağımız belirli bir politik mesajı vermek amacıyla—bir Davut heykeli yapılmasına karar vermiş, mermer üzerinde çalışmaya başlayan ilk usta mermeri yontmaya başlamış ama daha sonra işi bırakmıştır. Michelangelo mermeri bu aşamada almıştı ve ondan bir Davut heykeli

\footnotetext{
${ }^{1}$ Kuşkusuz bugün de pek çok sanatçı siparişle çalışıyor. Örneğin 2012 Londra Olimpiyatları için Damian Hirst sipariş üzerine Olimpiyat Stadı'nın zeminini tasarlamıştı. Ancak sipariş, söz konusu tasarımın ne olması gerektiği, ya da hangi renklerin kullanılması gerektiği gibi ayrıntıları içermiyordu. Tasarımın fiziksel olarak zemine yerleştirilmesi de Hirst'ün fiziksel çabalarıyla gerçekleştirilmesi beklenen bir iş̧ değildi. Günümüzde sanatçı yaratıcı bir fikir üretmekte iken Rönesans öncesi dönemde ve kısmen Rönesans süresinde bile sanatçılar var olan bir fikrin yaşama geçirilmesi için gerekli fiziksel işi gerçekleştirmekteydi.
} 
çıkarmaktan başka bir seçeneği yoktur. Eserin hangi politik mesajı vereceği bile işveren tarafindan seçilmiști. "O zaten oradaydı ben yalnızca fazlalıkları alıyorum" anlamında çeşitli ifadelerini belki de bu bağlamda değerlendirmek gerekir.

Davut heykelinin anlatması gereken öykü, Kutsal Kitap'ta Davut ve Golyat'ın savaşı ile ilgili bölümdü. I. Samuel 17. Bap'ta anlatılan öyküye göre Golyat, kimsenin karşısına çıkmaya cesaret edemediği üç metre boyunda bir savaşçıdır. Buna karşın genç ve çelimsiz bir çoban olan Davut onunla savașma cesareti gösterir. Davut daha önce hiç savașta yer almamıștır, öyle ki kral Saul'un kendisine verdiği zırh ve kılıcı tașıyamaz; onlarla yürüyemez ve onları çıkarttıktan sonra çoban kıyafetiyle Golyat'ın karşısına çıkar. Golyat onu görünce küçümser; değnek, sapan ve çoban torbasıyla gelen genç bir çocuktur Davut. Ancak sapanıyla başına taş attığı Golyat sersemleyip yere düştüğünde, gidip başını keser. Davut'un kılıcı bile yoktur; kullandığı kılıç Golyat'ındır. Öyküden çıkarmamız beklenen ders ise önemli olanın fiziksel olarak güçlü görünmek değil tanrının sevgili kulu olmak olduğudur. Floransalılar da kendilerini Davut'a benzeterek her düșmana karșı direnebileceklerini söylemektedirler —șehirden kaçmak zorunda bıraktıkları Medicilere hatta Medicileri destekleyen papalığa bile.

Ancak Michelangelo yaratıcı bir katk1 yapar ve o dönemin geleneklerine aykırı bir iş ortaya çıkarır. Öncelikle ortaya çıkan eser Golyat'ı içermez. Daha önce yapılmış ister resim ister heykel olsun hiçbir Davut temalı eserde Golyat tümüyle görmezden gelinmemiştir. Davut'un çoban torbası heykelde yer almadığ 1 gibi sapan da ancak arkadan bakıldığında görülebilmektedir; öyküde söz edilen beş çakıl da sağ avucunun içinde saklıdır. Önden bakıldığında elinde tuttuğu şeyin bir sapan olduğu anlaşılmamaktadır. Bütün bu ayrıntılardan çok daha önemli bir sorun ise Davut'un çelimsiz bir ergen olmak şöyle dursun atletik yapıda ideal ölçülerde bir figür olarak ortaya konmuş olmasıdır. Bugün için eserin sanatsal değerini tartışmak ve bunu yaparken öyküyü doğru ve kolay anlaşılır biçimde anlatmıyor olmasını umursamamak olanaklıdır. Ancak o dönem için bu son derece devrimci bir tutumdu. Her ne kadar aralarında da Vinci'nin de bulunduğu kurul eserin bir başyapit olduğunu kabul etse de heykel, sergileneceği yere taşınırken kimileri tarafından taşlanmıştır. 
Michelangelo bu eserinde, zamanda geri gidip Davut ile Golyat arasındaki savaşı izlesek ne göreceğimizi göstermek gibi bir amacı benimsememiș onun yerine hayranlık duyduğu Antik Yunan heykellerini taklit edip bir Yunan tanrısı heykeli ortaya koymuştur. Kendisine verilen işi yapmış görünmek için de heykelin eline bir sapan yerleştirmiştir. Heykelin aslında bir Antik Yunan heykeli olarak tasarlanmış oluşunun bir diğer göstergesi de çıplak olmasıdır. Eski Roma döneminden sonra yapılan ilk çıplak heykel Donatello'nun 1443 yılında tamamlanan bronz Davut heykeliydi. Bu heykel de Medici ailesi tarafından yaptırılmıştı. Golyat'ın kesik başı üstünde kılıcı ile duran, kadınsı hatları olan çıplak bir oğlan çocuğu betimleniyordu. Michelangelo'nun da kendi mermer Davut'una başlamadan önce bu heykeli gördüğünü biliyoruz. Ancak Donatello'nun heykeli Medici sarayının iç avlusunda gözlerden uzakta saklanmaktaydı. Michelangelo'nun çılak Davut'u ise herkesin görebileceği bir biçimde sergilenecekti. Michelangelo çıplaklığı, esere erotizm katan bir unsur olarak değil, Antikitenin üslubunun kullanımının gereği olarak görüyordu. Donatello'nun çıplak Davut'unun şapkası ve çizmesi varken, Michelangelo bu tür aksesuarlara yer vermemiști. Eserin ayakta durabilmesi için sağ ayağına bir destek yapılması gerekliliğini, öyküye ve yüzyılların geleneğine uygun olarak Golyat'ın kesik bașılyla karșılaması beklenirken de bir ağaç kütüğünü tercih etmiş, heykelinin konu nedeniyle Antik benzerlerinden farklılaşmasına izin vermemiști. William E. Wallace bu heykel için şöyle söylemektedir: "Rönesans'ın klasik Antikitenin 'yeniden doğuşu' olduğunu söylediğimizde, bunu hiçbir iş Michelangelo'nun Davut'undan daha iyi sergileyemez" (Wallace, 2009: 61).

$\mathrm{Bu}$ tür eserlerin ortaya çıkabilmesi için gerekli bir etmen de bunları finanse edecek kimselerin varlığıdır. Zira Davut gibi bir eser için gerekli mermerin bulunması ya da büyük bir duvara yapılacak Atina Okulu gibi bir freske yetecek boyanın temini bile ortalama bir sanatçıdan beklenemeyecek ölçüde büyük masraflardır. Kuşkusuz çeşitli krallıklar, böyle büyük projeleri finanse edebilecek güçteydi. Ancak talepleri bu tür sıra dış1 işler değildi. Çoğu, istenen öyküleri istendiği gibi anlatacak siparişe uygun çalışacak sanatçılar arıyordu.

Buna karşın Floransa'da ve Roma'da durum farklıydı. Floransa'daki Medici ailesi Antik Yunan eserlerini topluyor ve benzeri işlerin tekrar üretilmesini istiyordu. Roma'da da birkaç papa bu tür çalışmalar için gerekli kaynakları sağlamaktaydı; ancak Roma'daki kaynaklardan yararlanmaya 
zaten yetenekleri kanıtlanmış olanlar fırsat bulabiliyorlardı. Oysa Floransa'da gençler için olanaklar sunuluyordu. Lorenzo de' Medici, Antik Yunan eserlerini örnek alan yeni işler yapılmasını özendirmekteydi. Bunun için bir tür sanat okulu bile oluşturmuştu. Burada yetenekli gençler toplanıyor ve onlara bu eserleri çalışmaları öğütleniyordu. Üstelik Papalık ve Mediciler, Michelangelo için farklı işverenler değildi; hizmet ettiği üç papadan ikisi Medici ailesinin üyeleriydi (Papa X. Leo olarak Giovanni de Medici 1513-1521 ve Papa VII. Clement olarak Giulio de Medici 15231534). Sistine Şapeli'nin tavanını resimleme işini de sipariş eden diğer papa da (Papa II. Julius olarak Giuliano della Rovere 1503-1513), Medici ailesinin Floransa Cumhuriyeti'ni yıkıp yerine geçmelerini sağlayan yakın bir müttefikleriydi.

Michelangelo'nun klasik döneme öykünen eserler ortaya koyması kariyerinin belirli bir dönemine özgü değildir. Henüz 17 yaşındayken yaptığı ve Kentaurların Savaşı olarak bilinen yüksek kabartma birbirine geçmiş çıplak erkek figürlerinden oluşmaktadır. Eserle ilgili iki unsur özellikle dikkate değerdir. Öncelikle konu dini bir tema değil Medici sarayında aldığı eğitime uygun olarak mitolojik bir öyküdür. Ovid'in şiirinde insanlar ile Kentaurlar arasında geçen bir savaş konu edilmiştir. İkinci olarak Michelangelo öyküyü yaygın olarak betimlendiğinden farklı bir biçimde aktarmış hatta neredeyse anlaşılmaz hale getirmiştir.

\footnotetext{
Ancak Michelangelo'nun gerçekte anlattığı öyküyü anlamak zordur... Ne de Michelangelo'nun betimlediği karakterlerin kimlikleri tam olarak açıktır. Sahnenin altında merkezin hemen solunda bir kentaurun kalçası vardır, ve başka yerlerde bir atın ayağ1 ya da kuyruğu görülüveriyor, ama hangi karakterlerin insan hangilerinin kentaur olduğunu söylemek her zaman kolay değil...

Michelangelo öyküyü kendi düşünsel kaygılarına uyduracak biçimde değiştirmiş olabilir. Çıplak erkek bedeninin dışavurumcu potansiyelini araştırmayı, anlaşılır bir öyküyü yitirme pahasına tercih etmesi, Michelangelo'nun antikleri çalışırken öğrendiği dersi yansıtmaktadır (Campbell ve Cole 2012:321).
}

Görülüyor ki bir öykü anlatma çabası, bu erken yaşında bile Michelangelo için önemli değildir. Öte yandan bunun herhangi bir el alıştırması olamayacağı da açıktır. Çünkü $85 \mathrm{~cm} X 90 \mathrm{~cm}$ boyutlarındaki bu kalın mermer blok pahalı bir malzemedir. Michelangelo mermeri de böyle 
bir temayı da Lorenzo de' Medici'nin okulunda edinmiș olmalıdır. Ve ancak Lorenzo de' Medici'nin Antik Yunan'ı örnek alan anlayışı bir konuya sahip olmayan sanat eserleri çalışılmasına olanak verebilmektedir.

Michelangelo henüz 17 yaşındayken Lorenzo de' Medici ölmüş ancak aile sanatçıyı desteklemeye devam etmiştir. 1494 yılında çıkan ayaklanmada Floransa'dan kaçmak zorunda kaldıklarında bile Michelangelo'nun kariyeri ile ilgilenmeye devam etmiş ve Bologna'da kendisine bir iş verilmesini sağlamışlardır. Sanatçının yaşamı boyunca iki kez Floransa'dan cumhuriyetçiler tarafindan sürülen ve sonra tekrar șehri almayı başaran Mediciler, bir cumhuriyetçi olmasına karşın Michelangelo'yu sürekli desteklemişlerdir.

Bu desteğin öneminin en çarpıcı göstergesi, Medici ailesinden gelen iki papa arasında 1522 yılı başında papa olan VI. Hadrian'nın Sistine Şapeli fresklerinin, bir ibadethaneye yakışmadığı gerekçesiyle yok edilmesine ve yerine başka bir sanatçı tarafindan geleneksel bir freskin yapılmasına karar vermesidir (King 2003:314). Eser, VI. Hadrian papa seçilmesinin ardından kısa süre sonra öldüğü ve ardından seçilen papa da Medici ailesinden olduğu için korunabilmiştir. Ancak bu olay bize Michelangelo'nun işlerinin Medici ailesinin doğrudan desteği olmaksızın var olamayacağını açıkça göstermektedir. Michelangelo eserlerini yalnızca ilk ortaya çıkarabilmesi için gerekli kaynağı bulmanın ötesinde onların yok edilmemesi için bile Medici ailesine muhtaçtır.

Her ne kadar Michelangelo Davut'u hazırlarken gerçek insanları model almışsa da modellerinden herhangi birine benzeyen bir heykel ortaya koymamıştır. Bunun yerine modellerinden yola çıkarak olması gereken oranları belirlemeye çalışmıştır. İnsan vücudunun farklı parçalarının birbirine göre oranları her insanda farklı olsa da bunların bir doğrusu olduğu ve her insanın bu doğrudan pay aldığını düşünmektedir.

$\mathrm{Bu}$ hem Michelangelo'nun diğer eserlerinde hem de diğer önemli Rönesans sanatçılarında gördüğümüz bir durumdur. $\mathrm{Bu}$ dönemin anlayışının bir tür Platonculuk olarak nitelenebilmesinin nedeni de doğrudan deneyimlenemeyecek bu soyut formları arama çabasıdır. $\mathrm{Bu}$ durumun oldukça çarpıcı biçimde dile getirildiği bir ifade Raffaello'da bulunmaktadır. Yazdığı bir mektupta, güzel bir kadın imgesi yaratmanın 
zorluklarını anlatırken güzel bir tane çizebilmek için pek çoklarını görmek gerektiğinden söz eder. Gördüğü güzel kadınların hepsi olması gereken biçime ilişkin ipuçları sunmaktadır. Bu ipuçları arasında yolunu bulmasını sağlayanın ne olduğunu şöyle ifade eder: "zihnimdeki belirli bir idea" (Raffaello'dan aktaran: Talvacchia, 2007: 12). Doğanın incelenmesi kendi başına eserin nasıl olması gerektiğini ortaya koymaz. Doğanın sunduklarının "belirli bir idea"ya uygun olarak işlenmesinin sonucudur Raffaello'nun eserleri.

İtalyan Rönesans'ının sanat anlayışı Lorenzo de' Medici'nin okulunda yeşermeye başlamış, öykü anlatımları yerini çıplak figürlerin gerçekçi betimlemelerine bırakmaya başlamıştı. Ancak bu gerçekçilik aslında ideal bir formun arayışıdır. Anatomi çalışmaları, gerçek modellerin incelenmesi bu amaç için izlenen yoldur. Raffaello "güzel" formunun peşindeyken Michelangelo çok daha kapsamlı bir araştırma içerisindedir. Davut ya da Sistine Şapeli'nin tavanındaki Yaratılış gibi eserlerinde güzel Yunan tanrılarını betimlese de pek çok çizimi çirkin figürler de içermektedir. Michelangelo ideal formları ararken kendini estetik hazlarla kısıtlamamış şık giyimli figürler, güzel kadınlar yerine bu dünyayı aşan yücelikte her türlü çarpıcı formu ortaya koymuştur. Michelangelo için "gerçek sanat eseri ilahi kusursuzluğun gölgesidir." Tam da Platon'un mağara alegorisini anımsatan bu ifadesinden de çevremizdeki varlıkların gerçekçi betimlemeleriyle değil kusursuz formların anlatımıyla ilgilendiği görülmektedir.

\section{Yüzen Nesneler Üzerine Bir Düello}

$\mathrm{Bu}$ soyut form arayıșı Galileo'da da vardır. O da gözlemsel verileri "zihnindeki belli bir idea"nın 1şı̆̆ında değerlendirir. Galileo'nun Platonizm'ini görmek için yalnızca onun ortaya koyduğu savları değil, onlara hangi yoldan ulaştığını incelemek gerekir. Her ne kadar Dünya'nın hareketine dair söylemleri ve bu konuda Kilise ile girdiği çatışma daha çok biliniyor olsa da Galileo'nun bilime olan temel katkısı keşiflerinden çok bu Platonist yöntemi üzerinden gerçekleşmiştir. Nesnelerin suda batmasını neyin belirlediğine dair giriştiği tartışma bu yöntemi anlamamızı sağlayabilecek basit ve çarpıcı bir örnek sunar. 
Galileo, Arşimet'in çalışmaları 1şığında yoğunluk farkının hareketi açıklamada önemli bir araç olması gerektiğini düșünmektedir. Bunu başarıyla uygulayabildiği bir durum suda batmanın ya da batmadan yüzmenin açıklamasıdır. Buna göre cisimler eğer yoğunlukları sudan fazlaysa batarlar; sudan az ise yüzerler. Aristoteles'in bunu söz konusu cismin şekliyle açıklamasını da bir yanılgı olarak niteler. Galileo'ya göre şekil bu konuda hiç rol oynamamaktadır.

Ancak suda yüzen nesneler konusunda Aristoteles'in görüşlerini çürüttüğü iddiası Toskana'daki araştırmacılardan biri olan Ludovico delle Colombe tarafindan bir meydan okumayla karşılanmıştır. delle Colombe 1612 'de grandükün ve kimi başka meraklı soyluların da bulunduğu bir gösteride Galileo'yu hem de Galileo'nun yöntemiyle yenebileceğini söylemiştir. Sudan daha yoğun olan küçük fildişi levhalar, suya yavaşça bırakıldıklarında yüzmektedirler. Hiç kimse fildişinin sudan daha yoğun olduğuna itiraz etmediğinden bu deney açıkça yoğunluğu sudan fazla olan her nesnenin batmak zorunda olmadığını kanıtlar. Elbette bu, şeklin tek belirleyici unsur olduğunu kanıtlamaya yetecek bir deneysel kanıt değildir; ancak Galileo'nun yanıldığı göstermeye yeter. ${ }^{2}$

Ne var ki Galileo ikna olmamıştır. Galileo ilk bakışta ilgisiz görünen pek çok doğa olayının ortak bir ilkeyle açıklanabileceğini savunmaktadır. Bu konuda yoğunluk fikrini kullanarak oldukça yol kat etmiştir. Örneğin terazinin iki kefesinin nasıl hareket ettiğini, kaldıracın nasıl çalıştığını, serbest düşmeyi ve-fildişi deneyini görmezden gelirsek - suda batmayı; yalnızca yoğunluk farklarına dayanarak açıkladığını düşünmektedir.

Galileo pek çok aracın çalışmasını, pek çok nesnenin düşmesi ya da batmasını açıklamasını sağlayan bir ilkeden, çok özel bir deney durumu nedeniyle vazgeçmeye niyetli değildi. Levha 1slatılıp bırakıldığında batıyor, hızla atıldığında ya da keskin ucu suya değdirildiğinde batıyordu. $\mathrm{Bu}$ nedenle ilkece haklı olduğunu ancak bu deneyde gözden kaçan bir

\footnotetext{
2 Atle Næss, bunu Aristoteles'in görüşlerinin ne kadar önemsiz bir ayrıntı olursa olsun sofuca savunulduğuna örnek olarak anlatır (Næss 2005: 80-84). Konuyu Aristoteles'in fikirleri için temel bir nokta olarak gören bir yorum için ise bakınız (Biagioli 1993:159209). Bu tartışmanın Aristoteles fiziği açısında önemli olduğunu göstermekte Biagioli ikna edici görünmekteyse de genel olarak Galileo'nun devrimci savlarını, saraylı koruyucularını eğlendirmek için sıra dışı fikirler savunmak zorunda kalmasıyla açıklamaya çalışıyor olması fazlasıyla zorlama görünmektedir.
} 
ayrıntı olduğunu düşündü. $\mathrm{Bu}$ olay Galileo'nun deneysel veriler ve bütünleştirme çabası arasında nasıl bir denge gözettiğini ve bilimsel yönteminin basitçe gözlemsel veriler derlemekten ibaret olmadığını açıkça sergilemektedir.

Galileo, gösteriden sonra kendini savunmak ve bu gösterideki deneyi yoğunluk fikriyle açıklamak amacıyla görüşlerini yazar. Savunması yavaşça bırakılan levhanın altında bir miktar hava kaldığı varsayımına dayanır. Böylece özgül ağırlığın tek neden olduğunda 1srar eder. Bu çözüm doğru değildir; ancak Galileo'nun yaklașımı ve karșılaștığı sorunu ele alıș biçimi bilimsel tavra kusursuz bir örnektir. ${ }^{3}$

Zaten Galileo'yu asıl devrimci yapan özelliği-her ne kadar duyu verilerini kullanıyor olsa da—sağduyuya ve gözlemsel verilere açıkça aykırı olan iddiaları savunuyor oluşudur. Dünya'nın hareket ettiğini gösterecek bir kanıt bulmak bugün için bile pek kolay değildir. Galileo herhangi bir kanıta sahip değilken bu görüşü savunmuştur. Gerçekten de onun sahip olduğu araçlar ve kuramsal birikimle bunu göstermek pek olanaklı görünmemektedir. Üstelik sonunda gel-git olaylarının Dünya'nın hareketine bir kanıt oluşturduğunu sandığında da, kendi hesapları bile bir sorun olduğunu göstermekteydi.

Yani Galileo duyu verilerini kullanmakla birlikte, onları aşan ideal formları aramaktaydı. Doğanın dilinin geometri olduğunu söylerken, etrafımızda kusursuz çemberler, küreler göremeyeceğimizi biliyordu. Ancak bu dünyanın kusurlu varlıklarını gözlemleyerek, kusursuz formlar arasındaki ilişkileri çıkarsamanın olanaklarını aramaktaydı. İdeal formların aranışı, Raffaello'da ve Michelangelo'da olduğu gibi Galileo'da da temel bir yer tutmaktadır. Formlar arasındaki soyut düzenlilikleri bu dünyanın kaotik görünümünden türetme çabasındadır.

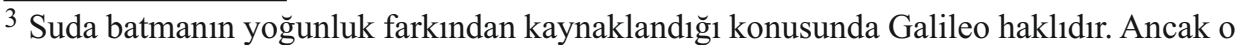
dönemde bilinmeyen nokta suyun moleküllerinin birbirine tutunmasıdır. Yüzey gerilimi olarak adlandırdığımız bu durum, suyun içine girmeye karşı bir direnç oluşturur. Bu nedenle bu yüzey gerilimini aşamayacak biçimde yavaşça yerleştirilen geniş yüzeyli ve hafif bir cisim, suyun içine giremediğinden, sudan yoğun olsa dahi batmaz. Kuşkusuz bunların hiçbiri o dönemde bilinmiyordu. Ancak bizim konumuz açısında önemli olan Galileo'nun bir yanıta sahip olmadığı, deneysel olarak görüşlerinin sorunlu olduğunu gördüğü durumda dahi görüşünde direnmesidir. Çünkü Galileo görünenin ötesinde bazı düzenlilikleri aramaktadır.
} 
Bunun Medicilerin Antik Yunan'a dönüş hevesinin uyumlu bir parçası olduğunu anlatan en açık çalışması teleskopuyla Ay'ı gözlemesidir. Ay yüzeyinde gördüğü kraterlerin göksel kürelerin mükemmel olmadığını kanıtladığını söylerken, Ay'ın büyükçe bir taş olduğunu iddia ediyordu. Galileo için bu büyük bir keşiftir. Çünkü iki bin yıldır astronomi çalışmaları yapılmaktadır. Ve bunlar geometrinin ideal formlarının gök cisimlerinin hareketlerine uygulanması yoluyla niceliksel bir araştırma biçimindedir. Öte yandan Aristoteles'e göre yeryüzü araştırmaları - tam da geometrik formların dünyada uyduğu varlıklar olmadığ 1 gerekçesiyle-yalnızca niteliksel olabilmekteydi. Galileo ise Ay'ın kusurlu bir taş olduğunu söyleyerek geometrik formların ideal olmayan varlıklara uygulanabilirliğini kanıtlamaktadır. Böylece niceliksel bir yeryüzü bilimi olanaklı hale gelmektedir. Galileo Antik Yunan temelli bilim yaklaşımını yanlışlamaya değil, uygulama alanını genişletmeye çalışmaktadır.

Galileo hakkında bilinen en ünlü öykünün Kilise ile girdiği Dünya'nın hareketine ilişkin tartışma olması bu bakımdan oldukça üzücüdür. Çünkü Galileo'nun bilimsel gelișmeye asıl katkısı yeryüzünde bozulan eskiyen kusurlu nesnelerin de niceliksel bilimin konusu olabileceğini göstermiş olmasıdır. Kilise ile girdiği tartışma yalnızca bunun ilkesel olarak olanaklı olduğunu gösterme çabası sırasında ortaya çıkan bir argümanla ilgilidir. Oysa Galileo ev hapsinde geçirdiği sürede asıl başyapıtını yazmış ve yeryüzü bilimini gerçekleştirmeye başlamıştır. Ölümünden hemen önce 1642 yılında Íki Yeni Bilim adıyla yayınlanan bu eser astronomi alanında pek bir sav içermemektedir. Amacı geometrik formlar ve oranlar aracılığıyla yeryüzündeki sıradan varlıkları incelemektir. Yani Galileo, Antik Yunan'ın astronomi için ayırdığı çalışma alanını yeryüzü de dahil tüm evrene genelleştirmiştir.

Bu görünenin arkasındaki ideal formları arama çabası sayesinde, duyularımız Güneş'in hareketinin apaçık olduğunu söylerken Galileo, hareket edenin Dünya olduğunu savunabilmişti. Eğer ağırlıkları farklı iki nesneyi aynı yükseklikten bırakırsak, ağır olanın daha önce düşeceğini bildiği halde, aynı anda düşmeleri gerektiğini bulabilmiști. Tıpkı Rönesans dönemi sanatçıları gibi gözlemlerinden yola çıkarak, gözlemlerin çok ötesinde hatta bazen onlara aykırı görünen sonuçlara ulaşabilmişti. 
Galileo'nun popüler öykülerde savunulan deney ve gözlemi baş tacı ettiği görüşünü Koyré ikna edici bir biçimde eleştirmektedir. Koyré yalnızca Pisa deneyinin aslında hiç yapılmamıș bir düşünce deneyi olduğunu göstermekle kalmamış (Koyré 2000:213-226) aynı zamanda Galileo'nun biliminin Platoncu dayanaklarını da ortaya koymuştur (Koyré 2000: 151-186).

Galileo için de Medici ailesinin varlığı, Michelangelo için olduğu kadar önemlidir. Her ne kadar Galileo'nun bilimsel çalışmalarında ihtiyaç duyduğu araçları sağlaması için çok zengin destekçilere gereksinimi yoktuysa da söylediklerinin ciddiye alınabilmesi için bir desteğe muhtaçtı. Günümüz bilim toplumunun aksine o dönemde eğer bir kimse matematikçi sıfatıyla bir üniversitede görev yapıyorsa oldukça sıradan bir konumda ve derin bir sav söyleyemeyecek durumda olduğu düşünülürdü. Copernicus'un 1543 basımı eserine Andreas Osiander'in yazdığı önsöz şöyle bitmektedir:

Gerçekten de birçok defa yapıldı ̆̆ gibi, tasavvurla ortay konan
nedenler hiç kimseyi tam anlamıyla ikna etmez, sadece
hesaplama için güvenilir bir temel oluşturur. ... matematikçi
tercihini kavranması en kolay olan hipotezden yana kullanır.
Oysa filozof ihtimaller peşindedir; mamafih hiçbir filozof
kutsal ilham kendisine gelmedikçe, kesinlikten payını alamaz.
$\ldots$. Bu hipotezler üzerinde dikkatle duran biri buradan, ... kesin
bir bilgi sunmaya muktedir olmayan astronomiden kesinlik
beklemesin. Sağlicakla (Copernicus 2010[1543]: 5-6).

Görüldüğü gibi Galileo'nun kimi hesaplamaların deneyle daha uyumlu sonuçlar verdiğini gösterecek biçimde çalışmalar yapması herhangi bir bilgi iddiasında bulunmasına yetmeyecekti. Öte yandan Medici ailesinin hizmetine girerken Toskana Grandüklügü̈nün matematikçisi ve felsefecisi sıfatını kazanmıştı. Onun görüşlerini gerçekliğin nasıl olduğuna ilișkin bir tartışmada dikkate almayı gerektiren bu unvan ve Medici ailesinin saygınlığıdır. Artık Galileo'yu ciddiye almamak Medici ailesine karşı bir saygısızlık sayılacağından Galileo'nun çalışmaları tüm araştırmacılar tarafindan izlenmekteydi.

Yine bu destek sayesindedir ki, engizisyonun yakılmaya kadar varan cezalar verdiği kimi görüşleri Kilise tarafindan görmezden gelinmiști. Sonunda yargılandığında bile rutin bir sorgu yöntemi olarak görülen işkence, Galileo'nun sorgusunda kullanılmamış ve yalnızca ev hapsi cezası verilmesiyle yetinilmiştir. 
Medici ailesinin Galileo'nun yetiştirilmesinde ya da onun fikirlerinin oluşumunda Michelangelo örneğinde olduğu gibi doğrudan bir etkileri olmadığı söylenebilir. Ancak şu iki noktayı gözden kaçırmamak gerekir, ilk olarak Galileo'yu da tıpkı Michelangelo'yu destekledikleri gibi desteklemişlerdir ve her ikisi için de bu destek o dönem başka hiçbir kaynaktan sağlanamayacak türden bir destektir. İkinci nokta ise Medici ailesinin tıpkı bugün anladığımız anlamda sanatı ve sanatçıyı yaratan bir güç olması gibi bilimi ve matematiksel yolla doğayı inceleyen bilimciyi de yaratmış olmasıdır.

\section{Medici Ailesi'nin Altın Çağı}

Raffaello, on altıncı yüzyılın başlarında Papa'nın kişisel kütüphanesinin duvarlarını - kütüphanedeki sınıflandırmaya uygun olarak-bilgi temalı fresklerle süslemişti. Üç duvarda, Kutsal Kitap'ın yorumlandığı bir sahne, ilahi esinle yazılmış şiir dinletisi içeren bir sahne ve son olarak da "eskinin bilgeliği’"ne atıfla Antik felsefe metinlerine ilişkin ünlü Atina Okulu freski yer almaktaydı. Kapının olduğu son duvarda ise hukuk temalı bir fresk bulunuyordu. Bizim bugün doğa bilimi olarak sınıflandıracağımız türden hiçbir etkinliğe değinilmemişti.

Her ne kadar freskler derinlik yanılsaması içeriyor, figürlerin giysilerinin kıvrımları bile modeller üzerinde yapılan çalışmalara dayanarak çiziliyorsa da, bu eserler soyut anlatılar sunmaktaydı. İsa ya da Platon'nun dıș görünüșünü kimse bilmediğinden figürleri tanımamızı sağlayan unsurlar görsel benzerlik değildir. Örneğin figürlerden birinin Platon olduğu ancak merkezi konumu, elindeki kitap gibi unsurlardan anlaşılabilmektedir. Görsel benzerlik açısından incelenecek olursa bu figür aslında da Vinci'ye benzemektedir. ${ }^{4} \mathrm{Bu}$ anlaşı1ırlığı sağlamak için anakronik unsurlar eklenmiş ve "gerçekte" Platon'un okulunda olsak göreceklerimizden çok farklı bir çizim yapılmıştır. Ancak bütün bunlar, Raffaello'nun başarısızlığı değil tam tersine olağanüstü becerisini ortaya koymaktadır. Çünkü İtalyan Rönesans'ı naif bir “olduğu gibi çizme” çabası değildir.

$\overline{4} \mathrm{Bu}$ eserde çizilen her figür ikili bir kimliğe sahiptir. Sembolik anlatım aracılığıyla incelendiğinde eski bir düşünür olan figürlerin her biri, Raffaello'nun bir çağdaşına benzemektedir. 
İşverenine itaat etmeye en az istekli sanatçı olan Michelangelo'da bu durum daha belirgin biçimde görülmektedir. Öykü anlatma ișini iyice savsaklayan ve istediği formları çalışmak için konuyu yalnızca bahane olarak kullanan Michelangelo oldukça kanlı geçmiş olan Cascina savaşını anlatan bir fresk yapması istendiğinde plan olarak bir göl etrafında pek çok farklı pozisyonda duran çıplak erkek figürleri hazırlamıştı. Bu sahnenin savaş başlamadan önce gölde yıkanmaktayken aniden saldırı haberini alarak sudan çıkıp telaşla hazırlanmaya çalışan askerleri anlattığını iddia ediyordu. Michelangelo'nun atletik yapıda çıplak erkek figürleri çizmedeki bu 1srarı, Antik Yunan heykel sanatına dayanır. Medici ailesi, bilinçli bir biçimde yeni bir altın çağ yaratma hevesiyle Antik Yunan'ı kendilerine örnek almaktaydılar.

17. yüzyıl'a gelindiğinde sanattaki Antik Yunan'a dönüşün bir benzeri doğa incelemesinde yaşanmaktaydı. Galileo bu süreçte yer almaktadır. Michelangelo'nun sanatı dönüştürdüğü gibi o da doğa incelemesini dönüștürmektedir. Her ikisinin de var olabilmesinin koşulu Medicilerin desteğiydi.

$\mathrm{Bu}$ desteğin boyutu ve biçimi de oldukça çarpıcıdır. Gerek Michelangelo örneğinde gerekse Galileo'nun durumunda Mediciler koruyucusu oldukları bu kişileri savunmak için olağanüstü zahmetlere girmişlerdir. Floransa'nın hakimi olmalarını sağlayan papalığa karşı çıkan, Kilise'nin öğretilerine ve emirlerine açıkça karşı gelmiş birini cezadan kurtarmaya çalışmak yetmezmiş gibi, ev hapsi cezasına karar verildikten sonra bile Galileo'nun oldukça konforlu bir yașam sürebilmesine özen göstermişlerdi. O kadar ki Papa, gözünün önünde böyle bir durum yaşanmasını alaya alınmak olarak görüp bir süre sonra ev hapsi cezasının Roma dışına taşınmasına karar vermişti. Elbette Mediciler gerekli düzenlemeleri yaptılar ve cezanın Papa'dan uzakta gerçekleştirilmesini sağladılar. Galileo'nun bu süre içinde çeşitli öğrencileri oldu ve bir kitap daha yazd. Mediciler sayesinde Kilise bunlarla ilgili hiçbir işlem yapmadı.

Michelangelo örneğinde durum daha da ilginçtir. Sanat anlayışını destekleyecek Medicilerden başka kimseyi bulmakta zorlanan sanatçı, Medici ailesini iki kez şehirden kovmayı başaran cumhuriyetçilere destek vermektedir. Daha sonra kilisenin aforoz edeceği ve 1498'de asılacak olan Girolamo Savonarola'nın da hayranıdır. Savonarola'nın asılmasından 
yalnızca on yıl sonra Sistine Şapeli'nin tavanını boyarken onun aforoz edilmesine yol açmış vaazlarına fazlaca göndermede bulunmuştur.

Michelangelo, Medicilerin Papa'nın ordusuyla birlikte Floransa'yı ikinci kez ele geçirdiği savaşın öncesinde kentin savunmasını düzenlemekle yetkili mimarıdır. Surları teftiş etmiş ve güçlendirmiştir. Bunun ardından 1530'da şehir düşüp Mediciler kontrolü ele geçirdiklerinde üçüncü bir ayaklanmayı önlemek için cumhuriyetçilerle herhangi bir yakınlığı olan herkesi ortadan kaldıracak bir cadı avı başlatmışlardı. Ancak șehrin savunmasını düzenlemiș olan Michelangelo bu süreçte hiç ceza almadığ1 gibi kendisine yeni projeler sunulmuş ve cömert ödemelerle sanatını sergilemesi istenmiştir.

Medici ailesi her iki durumda da bir “yeniden doğuş”u desteklemiş ve kendi çıkarları aleyhine olduğu durumlarda dahi, yeniden doğuşu besleyecek çalışmaları korumuştur. $\mathrm{Bu}$ yeniden doğuş basit bir biçim anlayışı ya da gözleme vurgudan ibaret değildir. Onun yerine konusu sekülerleşen, kaynağını dinden almayan yeni bir bilgi edinme yönteminin doğuşudur. Değişmez özlere ve ideal formlara yönelik bu arayış artık Osiander'in söz ettiği "ilahi esinle" değil, bu dünyanın gözlenmesi ile yapılacak soyutlamalar yardımıyla yürütülecektir. Medicilerin asıl büyük devrimci etkisi hem Galileo örneğinde hem de Michelangelo örneğinde hiçbir yarar sağlaması beklenmeyen işleri salt kendi değerlerini gözeterek korumuş olmalarıdır. Böylece Kilise'nin dini propaganda malzemesi olmayan sanat eserleri sırf "iyi sanat eserleri" olmak bakımından değerli görülmeye başlamıştır.

Nuremberg'li sanatçı Albrecht Dürer 16. yüzyılın başında İtalya'dan yazdığ 1 bir mektupta İtalya'dan neden ayrılmak istemediğini şöyle dile getirmiştir: "Burada ben bir lordum, evimde ise bir asalak" (Dürer'den aktaran Labno, 2012: 75). Çünkü başka yerlerin aksine İtalya'da özellikle Medici ailesinin getirdiği anlayış artık sanat eserlerinin bir son akşam yemeği freski ya da Meryem tablosu olmaktan önce bir da Vinci ya da bir Raffaello olmasına yol açmıştır. Artık sanat eserlerinin-konusunu umursamayanların gözünde bile-kendi değerleri vardır. Bunun en çarpıcı örneği Floransa'yı tekrar ele geçirdiklerinde Medicilerin kendilerine karşı gerçekleştirilen ayaklanmanın sembolü olan Davut'u korumalarıdır. Bunun sıra dışı bir davranış olduğu Michelangelo'nun bronz heykelinin başına 
gelenlere bakılarak anlaşılabilir. Michelangelo, Papa II. Julius'un yüksekliği dört metreden fazla ağırlığı ise dört buçuk ton kadar olan bronz bir heykelini yapmıştı. Heykel Alfonso d'Este tarafından Julius II'ye karşı yürütülen bir savaş sırasında ele geçirildiğinde top yapmak üzere eritilmişti. $\mathrm{Bu}$ işlem heykeldeki bronza duyulan bir ihtiyaçtan değil salt Julius II'yi aşağılamak amacıyla yapılmıştı. Üstelik Alfonso d'Este barışın sağlanmasından sonra Sistine Şapeli'nin tavanını görmek için özel bir çaba sarf etmiş, Michelangelo'yu da kendisi için de bazı işler yapması için ikna etmeye çalışmıştı (King, 2003). Oldukça yakın tarihlerde yaşanan bu iki olay, Medicilerin sanat eserlerinde konuları dışında bir değer gören böylece bugün anladığımız anlamda sanatın ortaya çıkışında büyük rol oynayan bir aile olduğunu göstermektedir.

Bilim için de durum oldukça benzerdir. Galileo'nun çalışmaları ne daha iyi savaş aletleri yapma konusunda ne de daha dayanıklı binalar yapmakta işe yaramaktadır. Dünya'nın mı yoksa Güneş'in mi döndüğü tartışması tümüyle yararsızdır. Ancak bu tartışmanın yürütülmesinin kendisi bilimsel bir sorgulama yönteminin gelișmesine yol açmaktadır. Medici ailesi bir yarar beklemeksizin Galileo'nun araștırmalarını salt bilimsel değeri bakımından önemsemiş ve onları korumak amacıyla papayla ilişkilerini zorlaştırmayı bile göze almışlardır. Galileo'nun eserlerini korumakla kalmamışlar, onu ev hapsi cezasıyla kurtarıp çalışmalarını sürdürmesine ve yeni öğrenciler yetiştirmesine de olanak sağlamışlardır. Bu anlamıyla Medici ailesi bilimin doğuşu için de kritik bir rol oynamıştır.

\section{Karıncalar, Örümcekler ve Arılar}

Galileo'nun çağdaşı Francis Bacon da bu yeniden doğuşun yeni dünya anlayışını anlamaya ve geliştirmeye çalışmıştır. Sistematik bir bilgi edinme yöntemi önerisi geliştirmiştir. Her ne kadar Bacon geometrinin bu yeni anlayışta oynaması gereken rolü anlayamamış ve geometriyi, bilgi edinmenin önünde kaçınılması gereken bir engel olarak betimlemişse de Bacon'ın yönteminde araștırılanın, görünenin ardındaki soyut formlar olduğu çok açikça ifade edilmektedir. Yöntemi bizi giderek daha genel ve daha soyut bir düzeye çıkarır. Bilgi piramidinde en alt düzeyde gözlemlerimiz vardır. Bunlardan elde edilen genellemeler ve soyutlamalar "aklın merdiveninde" bizi en üstteki formların bilgisine çıkartır. 
Bir anlamda ilk bilim felsefecisi olan Bacon, yeni bilimin yapısını oldukça güzel özetleyen bir metafor sunmaktadır. Buna göre empirisistler yalnızca toplayıp biriktiren karıncalar gibidirler. Naif bir toplama işlemi gelişmeye ve yeni keşiflere yol açamayacak yetersiz bir yöntemdir. Bunun karşısında rasyonalistler ise kendi zehrinden ağlar ören örümcekler gibidir. Bunların yalnızca kendilerine yararı olan ağları da ancak sorun yaratmaktadır. Oysa yeni bilimin yolu arıların yolu olmalıdır. Hem bitkilerden öz toplayan arılar gibi duyu verileri derlenmeli hem de onlar akıl yoluyla işlenmeli ve herkese yararlı olan bal elde edilmelidir (Bacon, 2000[1620]: Kitap I, XCV).

Modern bilim tam da bu fikir doğrultusunda çalışan araştırmacıların eseridir. Basitçe veri toplamanın çok ötesinde, ilgisiz görünen olaylar arasında ortaklıklar bulmaya çalışan Galileo, bu ortaklıkların geometrik ilișkiler olduğunu savunmuștu. Doğanın da tanrının eseri bir kitap olduğunu belirtirken onun yazıldı ğ 1 dilin geometri olduğunu söylediğinde anlatmak istediği buydu. Her ne kadar bu dünyada kusursuz çemberler ya da doğrular göremesek de, görünüşteki kusurların ötesine bakmanın bir yolunu aramaktaydı. Bunu diyalog biçiminde yazdığı kitapta açıkça belirtmektedir. Eserde Galileo'nun sorunlarını göstermeye çalıştığı, yaygın kabul gören Aristotelesçi görüşleri savunan Simplicio adlı karakterle bir kaç kez matematik ve Platonculuk tartışmasına girer. Bundan da Galileo'nun platoncu yaklaşımı farkında olarak benimsediğini anlamaktayız. Oldukça ikna edici bir dizi geometrik argümanın ardından Simplicio, Galileo'nun görüşlerini aktaran karaktere şöyle karşı çıkar:

Simplicio - ... Aristoteles ile birlik olarak Platon'un şu geometriye fazlaca daldığını ve fazlaca oyalandığını söylerim; çünkü ... matematiğin bu incelikleri soyut olarak doğrudurlar fakat gözle görülür elle tutulur maddeye ve fiziksel dünyaya uygulandığında sorunlara cevap vermiyorlar: Evet matematikçiler kendilerine özgü ilkeleriyle, örneğin "sphaera tangit planum in puncto [küre, bir düzleme tek bir noktada temas eder]" önermesini kanitlayabilirler; ama iş madde dünyasına gelince durum başka yöne doğru gidiyor: Demek istediğim, şu temas açıları, şu oranlar, bütün bunlar var ya; maddesel, gözle görülür elle tutulur dünya işlerine gelince tüm bunlar buharlaşıp yok oluyor (Galilei, 2008[1632]: 282-283).

Burada dikkat edilmesi gereken nokta Simplicio'nun ya da temsil ettiği düşünce geleneğinin geometriyi değersiz görmediğidir. Yalnızca 
geometriyi soyut bir formlar dünyasına ait kabul etmekte ve bu dünyadaki varlıkları incelemeye, dolayısıyla içinde bulunduğumuz dünyayı anlamaya yararı olamayacağını düşünmeleridir. Tıpkı Osiander'in yazdığı önsözde olduğu gibi matematikçi gerçeklik hakkında konuşmaya yetkili değildir.

İşte bilim için Medici ailesinin önemi bu noktada belirginleşmektedir. Sanatçıyı siparişi hazırlayan alt sınıftan bir usta olmaktan seçkin ve yaratıcı bir bireye dönüştüren Mediciler, Galileo gibi bir matematikçiye felsefeci unvanı da vererek onun gerçeklik hakkında söz söyleme yetkisini tanımışlardır. Böylece Galileo dünya dışı soyut formlar arası ilişkileri çalışırken, "elle tutulur” dünyanın yasalarını inceler hale gelmiştir.

$\mathrm{Bu}$ dönüşümün en çarpıc1 etkisi Copernicus'un kitabının yasaklanmasıdır. Yayınlanmasının ardından 73 yıl boyunca kitap, Kilise tarafından bir tehdit olarak görülmemiști. Matematiksel bir takım hesaplamalar içeren bir kitap, Dünya'nın gerçekten döndügünü söyleyemezdi. Ancak Medicilerin Galileo'ya verdiği payenin ardından matematik gerçekten neler olduğuna ilișkin bir ispat aracı konumuna yükselmekteydi. İște bunun ardından Kilise, Copernicus'un eserinin kutsal öğretiyle çelişen bir sav içerdiğini düşündü. Dolayısıyla Kopernik devrimini Copernicus'un başlattığını söylemek ancak anakronik bir yorum olur. ${ }^{5}$

\section{Devrimler}

Michelangelo'yu ve Galileo'yu sanatta ve bilimde yaşanmış devrimlerin önemli temsilcileri sayabileceğimiz açıktır. Her ikisi için de Medicilerin desteğinin yaşamsal olduğunu da gösterebildiğimi umuyorum. Ancak denilebilir ki eğer bu iki figür olmasaydı da, hatta Mediciler olmasaydı da, Rönesans ve Kopernik devrimleri yine de gerçekleşecekti.

Michelangelo dişında elbette pek çok Rönesans sanatçısı vardır. Ancak bunun hemen Michelangelo'nun ya da Medicilerin bu süreçteki rolünü önemsizleştireceği düşünülmemelidir. Örneğin Michelangelo'nun doğumundan yaklaşık 20 y1l önce Kutsal Aile ile Maria Magdalena, Jerome ve Hilarion adlı eseri yapan Filippo Lippi (1406-1469) önemli bir Rönesans

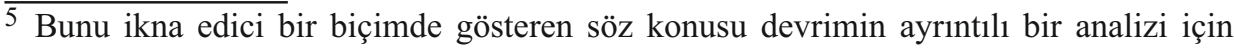
bakınız (Kuhn, 2007). 
sanatçısıdır. Papazken kutsal yeminini bozup bir rahibeyle kaçtığında yakalanmış ve işsence görmüştür. Ancak Lippi'nin yaşamına baktığımızda ressamlığa Floransa'da başladığını ve yeminini bozup, evlenmek için izin almasını da Medicilerin çabasına borçlu olduğunu görmekteyiz. ${ }^{6}$ Ve yine tıpk1 Galileo örneğinde olduğu gibi yeni Platonculuk diyebileceğimiz devrim tam anlamına Michelangelo ile kavuşmuştur. Zira önceki sanatçılar öykü anlatımına devam etmişler, öyküyü umursamayan form arayışlarına girişmemişlerdir. $\mathrm{Bu}$ konu günümüzden bakıldığında güçlükle fark edilmektedir. Çünkü örneğin Sistine Şapeli'nin en ünlü bölümü olan Adem'in Yaratılışı, tam da kutsal bir öykünün anlatımı gibi durmaktadır. Ancak daha dikkatli bakıldığında bir sorunla karşılaşmaktayız. Kutsal metinlerdeki yaratılış öyküsü Adem'in çamurdan yapıldığını ve tanrının ona, burnundan ruh üfleyerek can verdiğini anlatmaktadır. Bu nedenle Michelangelo'dan önce tüm yaratılış tasvirleri çamurdan şekillenmekte olan bir Adem ya da burnundan ruh üfleyen bir tanrı betimlemesidir. Dokunma biçimindeki yaratılış öylesine sıra dışıdır ki eseri inceleyenlerden Piskopos Giovio "yaşlı adamı" tanıyamadığını belirtmiştir (King 2003: 244).

Her ne kadar tarihe bir zorunluluk atfetmek tartışmalı olsa da Rönesans'ın Mediciler ya da Michelangelo ile doğrudan bir bağ 1 olmayan kaynakları da olduğu açıktır. Örneğin Giorgione (1477(?)-1510) Venedikli bir ressamdır. Floransa ile ya da Medici ailesiyle bir bağı olduğunu düşündürecek bir veri de elimizde bulunmamaktadır. Buna karşın eserlerinde tıpkı Michelangelo gibi dini öykülerin anlatımına yer vermemiştir. Ne var ki yirmili yaşlarının başında ölen bu sanatçının kendi başına çok büyük bir etkisi olamazdı. Nitekim çok daha sonra bile, Raffaello'nun izinden giden bir bașka Venedikli sanatçı Veronese, 1573 yılında yaptığı bir fresk yüzünden kutsal değerlere saygısızlık suçlamasıyla engizisyonda yargılanmıştır.

Bilimsel çalışmalar konusunda da Cizvit örgütü hiç de önemsiz sayılamayacak adımlar atmaktaydı. Yasaklanışına kadar Copernicus'un fikirlerine sıcak bakmış, teleskop gibi yeni araçları hızla benimsemişlerdi. Yine de matematiği kutsal metinleri yeniden yorumlamamızı gerektirecek güçte bir kanıt olarak kabul edebilecek tavra sahip değillerdi.

6 Ünlü bazı Rönesans eserlerini ve sanatçılarını kısaca tanıtan bir kaynak için bakınız (Labno, 2012). Burada bu sanatçıların çoğunun Floransa ve Medicilerle yakın bir temasları olduğu görülmektedir. 
Ancak benim de burada göstermek istediğim, bir kișinin Rönesans'1 ya da bilim devrimini tek başına gerçekleştirdiği değil. Yalnızca Michelangelo'nun ve Galileo'nun söz konusu devrimlerin çok temel fikirlerinin kaynağı olduklarını vurgulamak istiyorum. Aynı șekilde Medici ailesi de bütün bu süreçte kilit bir rol oynamıștır. Medicilerin nesiller boyunca hiç azalmadan süren Antik Yunan'ın yeniden keşfi ile yeni bir altın çağ yaratma arzuları, Michelangelo ve Galileo'nun dehaları ve Antik Yunan'ı ideal formların keşfi biçiminde anlamaları sayesinde büyük bir düşünsel devrime dönüşmüştür. $\mathrm{Bu}$ düşünsel devrim sanatçıyı öykü betimleyen biri olmaktan çıkartıp yaratıcı konumuna getirmiştir. Artık insanlar yaratılış öyküsünü görmek için değil bir Michelangelo görmek için Sistine Şapeli'ne gitmeye başlamıştır. Benzer biçimde Osiander'in gerçekliği ortaya çıkarma gücü atfedilmemesi gerektiğini söylediği, teknik ve ikinci sınıf bir alan olan matematik, Galileo'nun çabalarının ardından bilgiyi aramanın en güvenilir yolu haline gelmiştir. 


\section{KAYNAKÇA}

Bacon, F., (2000[1620]), The New Organon, ingilizceye çeviren: L. Jardine ve M. Silverthorne, Cambridge University Press.

Biagioli, M., (1993), Galileo Courtier, University of Chicago Press.

Campbell, S. J., ve Cole, M. W., (2012), A New History of Italian Renaissance Art, Thames \& Hudson.

Copernicus, N., (2010[1543]), Göksel Kürelerin Devinimleri Üzerine, çeviren: C. C. Çevik, İş Bankası Yayınları.

Galilei, G., (2008[1632]), İki Büyük Dünya Sistemi Hakkında Diyalog, çeviren: R. Aşçığlu, İş Bankası Yayınları.

King, R., (2003), Michelangelo and the Pope's Ceiling, Penguin Books.

Koyré, A., (2000), Bilim Tarihi Yazlları I, çeviren: Kurtuluş Dinçer, TÜBİTAK.

Kuhn, T. S., (2007), Kopernik Devrimi, çevirenler: H. Turan, D. Bayrak, S. K. Çelik, İmge.

Lobna, J., (2012), Rönesans, çeviren: E. Dastarlı, İş Bankası Yayınları.

Næss, A., (2005), Galileo Galilei-When the World Stood Still, Springer.

Talvacchia, B., (2007), Raphael, Phaidon.

Wallace, W. E., (2009), Michelangelo, Universe Publishing. 